\title{
Composition of Solvent-Extractable Organic Matter in Atmospheric Particles and Soils Collected at Scott Base, Antartica.
}

\author{
M. Radzi bin Abas ${ }^{1}$, Noorsaadah Abd. Rahman ${ }^{1}$, Nasr Yousef M.J. Omar ${ }^{1}$, Nik \\ Meriam Sulaiman ${ }^{2}$, Azizan Abu Samah ${ }^{3}$ and Bernad R.T. Simoneit ${ }^{4}$ \\ ${ }^{1}$ Department of Chemistry, University of Malaya, 50603 Kuala Lumpur, Malaysia. \\ *radzi@um.edu.my (corresponding author) \\ ${ }^{2}$ Department of Chemical Engineering, University of Malaya, 50603 Kuala Lumpur, Malaysia \\ ${ }^{3}$ Department of Geography, University of Malaya, 50603 Kuala Lumpur, Malaysia \\ ${ }^{4}$ Environmental and Petroleum Geochemistry Group, College of Oceanic and Atmospheric Sciences, \\ Oregon State University, Corvallis, OR 97331-5503, USA. \\ Received $4^{\text {th }}$ July 2008, accepted in revised form $26^{\text {th }}$ November 2008
}

\begin{abstract}
Atmospheric particulate matter and soil samples were collected around Scott Base, Antarctica and analyzed for solvent extractable organic compounds. Homologous compounds such as nalkanes, $n$-alkanols and n-alkanoic acids were present in all samples and are indicative of contamination from anthropogenic activities and to a lesser extent from natural microbial input. Extractable PAH and oxyPAH also confirm vehicular exhaust as a contributor to the organic particulate matter emitted into the atmosphere at Scott Base. Petroleum molecular markers such as pristane and phytane, as well as hopanes and steranes were also found in some soil and air samples. The concentrations of organic compounds were similar to those reported for rural locales in the northern hemisphere, suggesting that activities at Scott Base are contaminating the environment.
\end{abstract}

\begin{abstract}
ABSTRAK Sebatian-sebatian organik terekstrak dalam sampel jirim zarahan atmosfera dan tanah daripada Scott Base, Antarctica telah dianalisis. Hasil analisis mendapati bahawa sebatian-sebatian homolog seperti n-alkana, n-alkanol dan asid n-alkanoik wujud dalam semua sampel dan ini merupakan petunjuk bagi kontaminasi daripada aktiviti antropogenik dan sebahagian kecilnya daripada input mikrobial semulajadi. Kehadiran sebatian-sebatian HAP dan oksi-HAP juga mengesahkan eksos kenderaan sebagai penyumbang kepada jirim zarahan organik dalam atmosfera Scott Base. Petanda molekul petrolium seperti pristana dan fitana, dan hopana dan sterana juga ditemui dalam sesetengah sampel tanah dan udara. Kepekatan sebatian-sebatian yang diperolehi juga sama dengan nilai-nilai yang pernah dilaporkan bagi kawasan luar bandar di hemisfera utara. Ini menunjukkan bahawa aktiviti-aktiviti di Scott Base sebenarnya menyumbang terhadap kontaminasi di persekitarannya.
\end{abstract}

(Total suspended particles, solvent-extractable organics, air pollution, Scott Base, Antarctica)

\section{INTRODUCTION}

Antarctica is still considered as one of the most pristine areas of the world. However, its pristine environment has not escaped from been affected by human activities. Activities such as scientific research, research support facilities, shipping, tourism and fishing $[1,2]$ require fuel storage and consumption that result in a widespread hydrocarbon contamination in soils and sediments around current and former scientific research stations $[3,4,5]$.
Another source of contaminants found in Antarctica is the long-range transport of for example, priority organic pollutants (POPs) from the lower latitudes $[6,7,8]$. In addition, a recent study by [9] found high concentrations of highly toxic butyltins (commonly used as an antifoulant on ships) in the sediments at McMurdo Station, Antarctica.

However, local impacts due to the increasing presence of human activities, particularly at the research stations are inevitable. The combustion of fuel (for transportation and energy production) waste incineration, sewage and accidental oil 
spills are among the main sources of contaminants in Antarctic air, snow, soil and biota [10]. Accordingly, several contamination problems have been reported from many Antarctic stations [4]. A recent study has suggested that human habitation is by far the most significant source of polybrominated diphenyl ether (PBDEs) flame retardants in the Antarctic [11]. This new finding indicates that other contaminants associated with modern living lifestyles such as pharmaceuticals, personal care products, and perfluorinated compounds are also likely to be of concern.

Scott Base is New Zealand's permanent research support station in Antarctica located $10 \mathrm{~m}$ above sea level at Pram Point, Hut Point Peninsula,
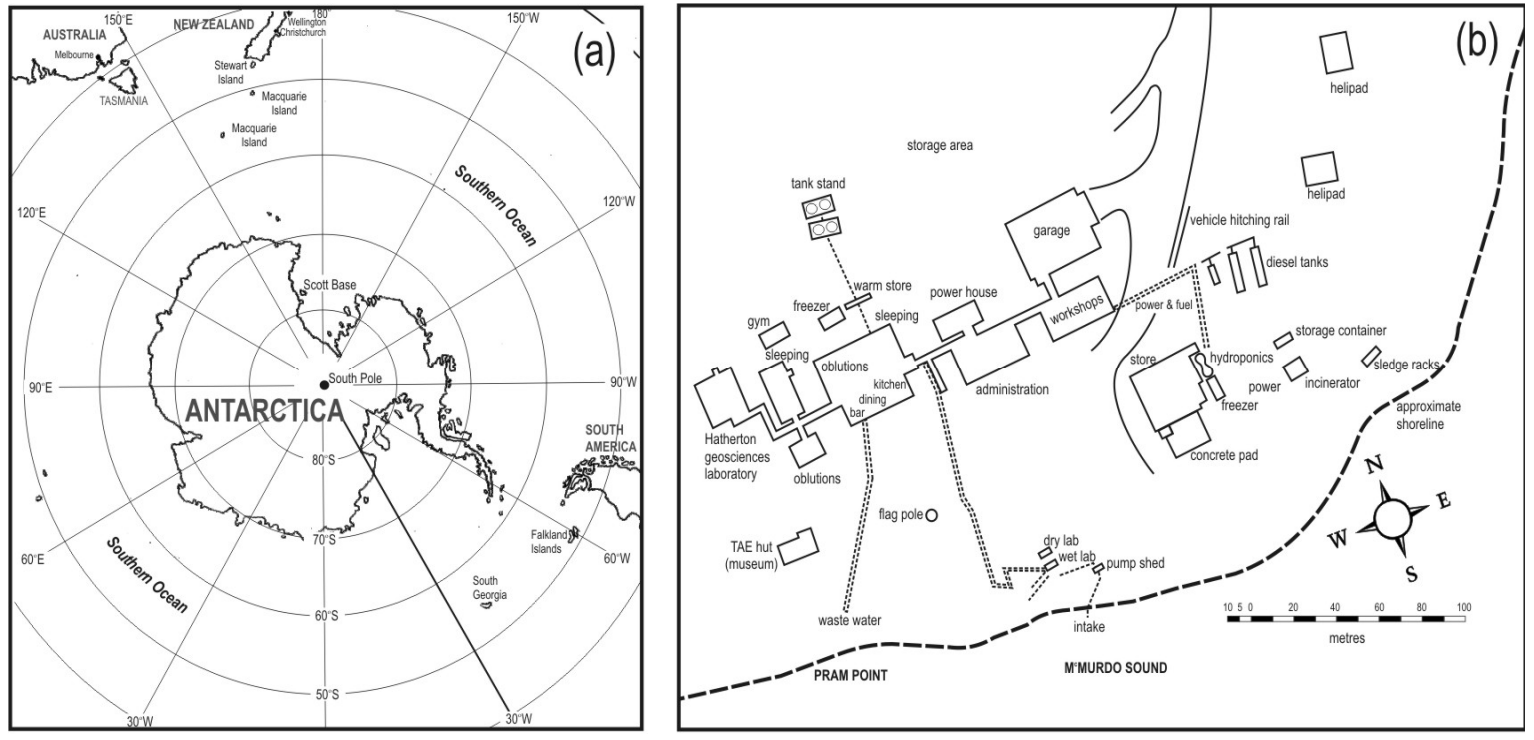

Ross Island, McMurdo Sound (Latitude, $77^{\circ} 51^{\prime} \mathrm{S}$, Longitude, $\left.166^{\circ} 46^{\prime} \mathrm{E}\right)$ on an ice-free, solid rock and frozen moraine surface (Fig. 1(a)). The base is about $3 \mathrm{~km}$ away from McMurdo station. It was built in 1957 and was rebuilt in 1976 following a fire. In 2005, Antarctica New Zealand which is responsible for the year-round running of the station, commissioned a twostorey, 1800 square meter heated Warm Store at Scott Base, the largest single construction project undertaken since the original commissioning of Scott Base in 1957. At present houses about 86 researchers and support staff during austral summer.

Fig.1 Location map of (a) Scott Base in Antarctica and (b) the general map of Scott Base showing the sampling locations (1-4).

Being an active research station it is plausible that some significant contamination of the surrounding areas would occur. However, there had been very few studies on soils and sediments around and adjacent to Scott Base $[1,9,12]$. To our knowledge, to date there has been no study carried out on the characterization of solvent-extractable organic compounds in air particles and soils collected in the vicinity of Scott Base. The objective of this study is therefore, to characterize the principal organic contaminants in the atmosphere and soils around Scott Base and to relate them to their potential sources. Air particulate samples as well as soil samples were collected and analyzed in order to assess the impact of human activities in such a remote location. These observations and findings 
the tower (200 m above-ground); (3) the incinerator (close to an incinerator); (4) the garage (close to a mechanical workshop) (Fig. 1(b)). The atmospheric conditions prevailing on the days of sampling are given in Table 1 .

A total of 19 air particulate samples were collected during the spring 1999, winter 2000 and summer 2001 seasons. In addition five soil and one incinerator ash samples were also collected (Table 2).

Air particulate samples were collected using a TSP high-volume air sampler (Tisch Environmental Inc, USA) fitted with quartz fiber filters $(20.3 \mathrm{~cm} \times 25.4 \mathrm{~cm}$, Whatman, England), and operated at a flow rate of $\sim 1.04 \mathrm{~m}^{3} \mathrm{~min}^{-1}$. Each sampling was carried out over a 24-h period. The quartz fiber filters were annealed for 4-8 hours at $500^{\circ} \mathrm{C}$ prior to sampling in order to pyrolyze and thus removed any adsorbed organic materials and wrapped with aluminium foil.

Before weighing, all fresh and exposed filters were conditioned for 24 hours in a chamber where the temperature was maintained at $25^{\circ} \mathrm{C}$ with a relative humidity at $45 \%$. The exposed filters were then stored in a precleaned jar to which approximately $5 \mathrm{ml}$ of dichloromethane $\left(\mathrm{CH}_{2} \mathrm{Cl}_{2}\right)$ was added to inhibit growth of microbes and then stored at $4{ }^{\circ} \mathrm{C}$ until analysis. Field blanks were obtained by the method used for real sampling, except for exposing a filter to the air for a few seconds.

The filters were then cut into small pieces and extracted three times in the filter storage jar using ultrasonic agitation for a 15-min period each with $100 \mathrm{ml}$ of dichloromethane/methanol mixture $(3: 1 \mathrm{v} / \mathrm{v})$. The extracts were then filtered using a filtration unit with an annealed glass fiber filter to remove insoluble particles. The filtrate was first concentrated on a rotary evaporator and then by a stream of dry nitrogen gas to a volume of approximately $2 \mathrm{ml}$. The volume of the extract was then adjusted to $2.0 \mathrm{ml}$ exactly by addition of dichloromethane.
About $10 \mathrm{~g}$ of air-dried soil particles (sieved $\leq$ $600 \mu \mathrm{m}$ ) were extracted by ultrasonic agitation. Three $15 \mathrm{~min}$ extractions were carried out in centrifuge tubes with $20 \mathrm{ml}$ of dichloromethane/methanol mixture $(3: 1 \mathrm{v} / \mathrm{v})$ each time. The combined extracts were then filtered, concentrated and made up to $2.0 \mathrm{ml}$ with dichloromethane.

Half milliliter aliquots of the extracts were derivatized by reaction with $\mathrm{N}, \mathrm{O}$-bis(trimethylsilyl)-trifluoroacetamide (BSTFA) plus $1 \%$ trimethylchlorosilane (TMCS) and a trace of pyridine for $15 \mathrm{~min}$ at $70^{\circ} \mathrm{C}$. The derivatized extracts were then concentrated to $50.0 \mu \mathrm{l}$ and subjected to GC-MS analyses on a HewlettPackard Model 6890 gas chromatograph-mass spectrometer fitted with a fused silica capillary column coated with $5 \%$ phenylmethylsiloxane (HP-5MS, $30 \mathrm{~m}, 0.25 \mathrm{~mm}$ i.d, $0.25 \mu \mathrm{m}$ film thickness). Detailed description of the method used for quantification and QA/QC confirmation can be found in Omar et al. [13].

For each sample, $1.0 \mathrm{ml}$ aliquot of the extract was transferred to a preweighed vial, evaporated to dryness using a stream of dry nitrogen gas, and quantified by weighing the dry aliquot on an analytical balance (Table 2, total solvent extractable organic matter (TSEOM)).

\section{RESULTS AND DISCUSSION}

General characteristics of the samples collected such as sampling locations, dates, total solvent extractable organic matter (TSEOM), and total suspended particles (TSP) are given in Table 2. The analytical data for the identified organic compounds are listed in Table 3 (spring atmospheric particles), Table 4 (winter and summer atmospheric particles), and Table 5 (soils and ash). The average atmospheric concentration and distribution of polycyclic aromatic hydrocarbons (PAHs) and oxygenated polycyclic aromatic hydrocarbons (oxy-PAHs) at location 4 (garage) is shown in Figure 2. 


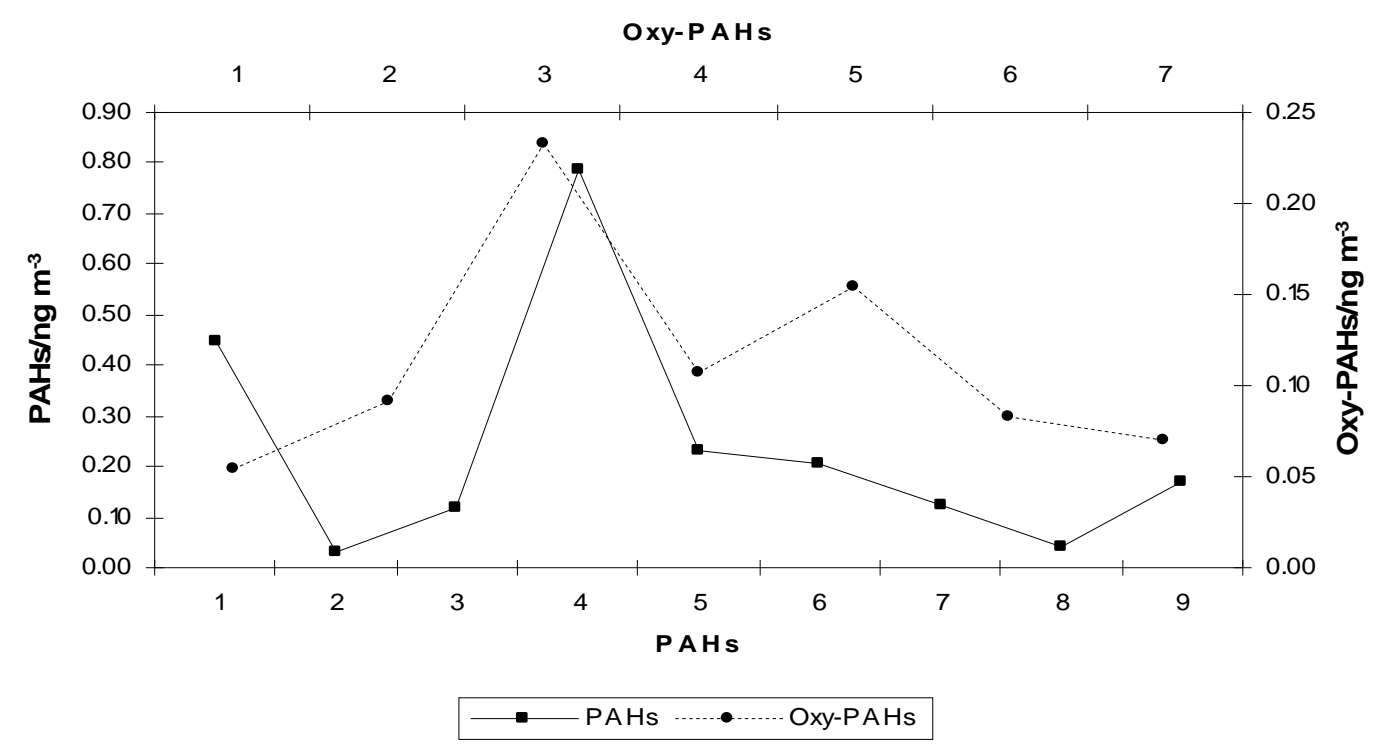

Fig 2 Graph of average atmospheric concentration vs. distribution of PAH and Oxy-PAH at location 4 (garage). PAHs: 1=Phenanthrene, 2=9-Ethenylanthracene, 3=4,5-Methylenephenanthrene, $4=$ Fluoranthene, $5=$ Benzo $[$ ghi $]$ fluoranthene, $6=$ Chrysene, $7=$ Benzo $[a]$ pyrene, $8=$ Indeno[1,2,3-cd $]$ pyrene, $9=$ Coronene. OxyPAHs: $1=$ Cyclobuta $[b]$ naphthalen-1(2H)-one, $2=9 \mathrm{H}$-Fluoren-9-one, $3=1 \mathrm{H}-\mathrm{Ph}$-nalen-1-one, $\quad 4=9,10$ Anthracenedione, $\quad 5=1 \mathrm{H}, 3 \mathrm{H}-\mathrm{Naphtho}[1,8-c d]$ pyran-1,3-dione, $\quad 6=7 \mathrm{H}$-Benz $[d e]$ anthracen-7-one, $\quad 7=4 \mathrm{H}$ Cyclopenta[def]chrysen-4-one.

\section{TSP and TSEOM data}

The sources of total suspended particles (TSP) in Scott Base may include: (1) geological dust from exposed soil surfaces (roads, parking lots and construction operations), (2) power generators (diesel-powered), (3) diesel and gasoline motor vehicles, (4) space heating by steam boilers and forced hot air heaters, (5) sea salt aerosols, and secondary sulfate and nitrate as is the case for McMurdo Station [14].

Mazzera et al. [15] reported an average PM-10 aerosol concentration at Hut Point, located less than $1 \mathrm{~km}$ from the center of McMurdo Station, of $3.4 \mu \mathrm{g} \mathrm{m}^{-3}$. This consisted of soil dust (57\%), sea salt (15\%), fossil fuel combustion emissions $(14 \%)$, sulfates $(10 \%)$, marine biogenic emissions as methanesulfonate (3\%), and nitrates $(1 \%)$. Soil dust, sea salt, and combustion sources accounted for $12 \%, 8 \%$, and $20 \%$, respectively, of PM-10 sulfates. The remainder was attributed to marine biogenic (36\%) and other sources (24\%) including emissions from Mt. Erebus and transport from distant combustion sources.

In this study the atmospheric TSP values were found to vary from 15.41 to $34.84 \mu \mathrm{g} \mathrm{m}^{-3}$, with the lower value observed for the Tower site (200 $\mathrm{m}$ above ground) and the higher obtained near the Garage location (Table 2).

The total solvent extractable organic matter (TSEOM) values for the atmospheric samples were in the range of 308 to $2705 \mathrm{ng} \mathrm{m}^{-3}$ (Table 2). The high concentrations of TSEOM may be due to the presence of fatty acid salts that are abundant in marine aerosols (e.g., [16,17]). For the soil samples, the TSEOM values measured varied from 46 to $424{\mu g g^{-1}}^{-1}$ (Table 2).

The principal organic compounds identified in these samples are n-alkanes, $\mathrm{n}$-fatty alcohols (nalkanols), n-fatty acids (n-alkanoic acids), petroleum biomarkers, and polycyclic aromatic hydrocarbons (PAHs) and their oxygenated analogues (oxy-PAHs). Unfortunately, these compounds were found to be randomly distributed in the samples and no distinctive patterns could be observed for proper source attribution. Nevertheless, the occurrence of some compounds (e.g., PAH) can still provide an insight into the anthropogenic activities that perturb the environment in this region. 


\section{Organic composition of Antarctic atmospheric and soil samples n-Alkanes}

The source of n-alkanes can be attributed to both biogenic (e.g., microorganisms and higher plants) and petrogenic origins (i.e. fossil fuel combustion emissions), and based on their distribution patterns the input of such sources to environmental samples can be distinguished [18]. Terrestrial lipids (i.e., $n$-alkanes, $\mathrm{n}$-alkanols and n-alkanoic acids $>\mathrm{C}_{22}$ from higher plant waxes) as described for atmospheric samples from the South Atlantic $\left(30-70^{\circ} \mathrm{S}\right)$ were not detectable in these samples [19].

In the atmospheric samples, n-alkanes were found to be in the range of $\mathrm{C}_{17}$ to $\mathrm{C}_{36}$. Their total concentrations varied from 0 to $3.8 \mathrm{ng} \mathrm{m}^{-3}$ (Tables 3 and 4), with the highest observed for the location at the garage, reflecting the contribution from vehicular emissions. The minor $n$-alkanes $>\mathrm{C}_{28}$ in some aerosol samples and incinerator ash show no significant carbon number predominance as is typical for higher plant wax. Their occurrence in the incinerator ash and absence in some of the aerosols sampled during the same period preclude long-range transport as mentioned above and indicates a local anthropogenic origin (e.g., burning of paraffin wax coated containers). However, the origin of lipid compounds from marine microbiota cannot be ruled out. The main wind flow at the coast is from the south and it has been reported that this air mass contains methanesulfonate of a marine biogenic origin [19]. A recent study reported the presence of $n-$ alkanes ranging from $\mathrm{C}_{16}$ to $\mathrm{C}_{20}$ in cyanobacterial mats communities of McMurdo Ice Shelf [20]. Thus, n-alkanes from marine sources could have reached Scott Base via atmospheric transport.

n-Alkanes in the soil samples ranged from $\mathrm{C}_{14}$ to $\mathrm{C}_{26}$ and their total concentrations varied from 18.1 to $530 \mathrm{ng} \mathrm{g}^{-1}$, whilst for incinerator ash, they ranged from $\mathrm{C}_{14}$ to $\mathrm{C}_{37}$ with a total concentration of $710 \mathrm{ng} \mathrm{g}^{-1}$ (Table 5). As a comparison, n-alkanes with chain lengths from $\mathrm{C}_{9}$ to $\mathrm{C}_{14}$ were detected in contaminated soils around Scott Base [21]. The presence of $n$ alkanes with chain lengths from $\mathrm{C}_{9}$ to $\mathrm{C}_{14}$ may be attributed to JPS-AN8 aviation diesel since short-chain n-alkanes are predominant in this fuel [22]. However, short-chain alkanes were not found in the soils in this study. Presumably, the evaporation of low molecular weight $n$-alkanes could have occured, because liquid fuels with a high vapour pressure such as jet fuel and mogas are readily volatilized from the Antarctic soil [23]. The loss of low molecular weight $n$-alkanes may also be due to biodegradation [24].

\section{n-Alkenes}

n-Alkenes were only found in the incinerator ash sample and they ranged from $\mathrm{C}_{15}$ to $\mathrm{C}_{26}$ with a total concentration of $127 \mathrm{ng} \mathrm{g}^{-1}$ (Table 5). The source of these $n$-alkenes is non-specific and may originate from incomplete combustion of biogenic waste (thermal dehydration of $\mathrm{n}$ alkanols present in biomass [18]) or fossil fuels (oxidation of n-alkanes [25]).

\section{n-Alkyl nitriles}

Only hexadecyl nitrile and heptadecyl nitrile were detected in the incinerator ash (Table 5). These compounds were proposed to be the products of the reactions of $n$-alkanoic acids with ammonia during thermolytic processes [26].

\section{n-Alkanols}

n-Alkanols were observed in both the aerosol particles and soil samples and ranged from $\mathrm{C}_{9}$ to $\mathrm{C}_{22}$ (Tables 3, 4, and 5). n-Octadecanol $\left(\mathrm{C}_{18}\right)$ is the most abundant alkanol isolated. This alcohol is also present in incinerator ash, which may indicate its origin from incineration of biogenic waste such as vegetables and vegetable oil. It has also been reported that phytoplankton produce n-alkanols with carbon chain lengths less than $\mathrm{C}_{20}$ with $\mathrm{C}_{18}$ being most abundant [27,28]. Similarly, algae and other microorganisms produce n-alkanols $<\mathrm{C}_{20}$ [29]; however, they are probably minor contributors to these alcohols due to their low prevalence in this region. Nevertheless, it is possible for these alkanols to also originate from the marine microbiota and could have reached Scott Base in the same way as described above for the $n$ alkanes. No alkanols from terrestrial higher plant wax $\left(>C_{20}\right)$ were detectable.

\section{n-Alkanoic Acids}

Vehicular exhausts (diesel and gasoline) emit nalkanoic acids in the range of $\mathrm{C}_{10}$ to $\mathrm{C}_{24}$ with a carbon number maximum, $\mathrm{C}_{\max }$, at $\mathrm{C}_{16}$ and $\mathrm{CPI}$ values $<4$ [29], whilst microbial sources produce $n$-alkanoic acids $<\mathrm{C}_{20}$ with a $\mathrm{C}_{\max }$ at $\mathrm{C}_{16}$ and CPI values $>3$ (available data for CPI values were calculated for the full range of $n$-alkanoic acids and not only for homologs $\left\langle\mathrm{C}_{20}\right.$ ) [30]. Higher plants produce the same alkanoic acids $\left\langle\mathrm{C}_{20}\right.$ as microbiota with additional homologs from $\mathrm{C}_{20}$ to 
$\mathrm{C}_{34}\left(\mathrm{CPI}>4\right.$ and $\mathrm{C}_{\max }$ at $\mathrm{C}_{16}$ and $\mathrm{C}_{24}, \mathrm{C}_{26}$ or $\mathrm{C}_{28}$ [30].

In all samples, the $n$-alkanoic acids were found to be in the range of $\mathrm{C}_{7}$ to $\mathrm{C}_{21}$. The total concentrations in the atmospheric samples varied from 1.16 to $19.9 \mathrm{ng} \mathrm{m}^{-3}$ (Tables 3 and 4), while the total concentration in the soils varied from 74.9 to $533.6 \mathrm{ng} \mathrm{g}^{-1}$ (Table 5). The measured CPI values for the samples obtained near the garage (5.25 and 4.65) and incinerator (1.57 and 4.26) are comparable to those of the atmospheric samples from the other locations around Scott Base (1.27 to 6.80, Table 3 and 4). This implies that vehicular and incinerator emissions are the major sources of $n$-alkanoic acid found in the atmospheric samples. The absence of alkanoic acids $>\mathrm{C}_{20}$ indicates that there is no input from long range transport of continental higher plant matter [19].

The soil samples collected at Arrival Heights and the summer lab have CPI values close to those of the atmospheric particles (4.97 and 5.01, Table 5 ) indicating a similar origin of the $n$-alkanoic acids in these samples. The CPI value for the flagpole soil sample was 11.02 , while that collected at the garage had no odd $n$-alkanoic acids resulting in a maximum CPI value (Table 5). Despite their trace presence, microorganisms and phytoplankton could have contributed $n$ alkanoic to these samples [27,28]. For the incinerator soil, the relatively high CPI value observed (7.50) could be due to direct contamination from the incinerator house where the CPI value of the incinerator ash was found to be 20.42 (Table 5).

\section{Petroleum biomarkers}

Pristane and phytane are hydrocarbons present in diesel fuel, lubricating oil, and in both auto and diesel engine exhausts [29,31]. Their presence usually indicates the contribution of petroleum residues to the environment. However, these hydrocarbons were not detected in the atmospheric samples but were found in two soil samples collected near the garage and the Summer Lab (Table 5).

Hopanes and steranes are not present in gasoline and diesel fuel because they belong to the higher boiling fraction of crude petroleum. They are, however, commonly found in lubricating oil and thus are present in both auto and diesel engine exhausts [29,31]. These compounds are relatively nonvolatile, not easily biodegraded as many other alkanes, geologically mature (formed over millions of years), and relatively stable in the environment. Hence, they are commonly utilized as molecular markers for the contribution of vehicular exhaust (e.g. [29,31]). In the current study, the $17 \square(\mathrm{H}), 21 \square(\mathrm{H})$ hopanes in the range of $\mathrm{C}_{29}$ to $\mathrm{C}_{33}$, including the $22 \mathrm{~S}$ and $22 \mathrm{R}$ epimers for $\mathrm{C}_{31}$ to $\mathrm{C}_{33}$, were present in some atmospheric and soil samples (Tables 35). However, $\mathrm{C}_{29} \square \square \square$ - and $\square \square \square$-steranes with the $20 \mathrm{~S}$ and $20 \mathrm{R}$ isomers were only detected in some soil samples (Table 5). The presence of hopanes and steranes in some atmospheric and soil samples confirms a minor input of petroleum residues.

\section{PAHs and oxy-PAHs}

The occurrence of PAHs in the environment is due to both natural and anthropogenic sources. Natural sources of PAH include forest fires and volcanic activities, while anthropogenic sources are from various types of combustion (e.g., internal combustion engines) and industrial processes (e.g., catalytic cracking in the petroleum industry). Due to their mutagenic and carcinogenic potentials, the atmospheric and soil concentrations of PAHs have been measured and reported for Antarctica (e.g. [1,3,32,33]. Total atmospheric PAHs ranged from 40-390 $\mathrm{pg} \mathrm{m}^{-3}$ over a three year period at the Italian Antarctic Base [33].

For the samples collected in this study, PAHs were only present in the atmospheric samples from the garage, where their origin can be attributed solely to diesel and gasoline motor vehicles. These PAHs ranged from phenanthrene ( 3 rings) to coronene ( 7 rings) and their total concentration was $2.16 \mathrm{ng} \mathrm{m}^{-3}$. Fluoranthene (4 rings) was found to be the most abundant PAH followed by phenanthrene (3 rings) (Fig. 2). The high abundance of the lower molecular weight PAHs is indicative of diesel vehicle emissions $[34,35]$. The absence of PAHs in the other samples implies that the activities in the vicinity of the garage are localized and do not adversely affect the other parts of Scott Base.

As a comparison, PAHs levels ranging from 41 to $8105 \mathrm{ng} \mathrm{g}^{-1}$ (d.wt.) were measured in contaminated soils near Scott Base and at two former research facilities at Marble Point and Wright Valley [1]. The same study also reported PAHs levels to be below detection limits at control sites. The absence of PAHs in the soils in our study could be the results not only of a low 
rate of production from the sources in the station but also a possible high migration rates of PAHs toward the adjacent Ross Sea.

Oxygenated PAHs (i.e., polycyclic aromatic ketones and polycyclic aromatic quinones) were also detected only in the atmospheric samples from the garage. Their total concentration was found to be $0.8 \mathrm{ng} \mathrm{m}^{-3}$ (Fig. 2). Oxy-PAHs are characteristic molecular markers for diesel exhaust and to a lesser extent for gasoline exhaust [29].

\section{CONCLUSION}

The compounds such as n-alkanes, n-alkanols and n-alkanoic acids extracted from all the samples collected around Scott Base have short carbon chain lengths (mainly $<\mathrm{C}_{20}$ ) and are indicative of anthropogenic contributions (vehicle traffic) and to a lesser extent of a microbial input from local and marine sources. Input from long range transport of terrestrial higher plant detritus is not detectable. PAHs and oxy-PAHs indicate vehicular exhaust as a contributor to the organic particles emitted into the atmosphere at Scott Base. The presence of pristane and phytane, as well as hopanes and steranes in some soil and air samples further support an input from vehicle traffic. A measurable input of anthropogenic contaminants into the local area of Scott Base has been determined, suggesting that human activities are significant contributor to input of contaminants to the local environment. Many organic compounds were not detected in the atmospheric and soil samples. Thus, acquiring aerosols for longer periods and extracting larger soil samples are recommended for future assessments. Also, the wind directions or air parcel back-trajectories need to be determined in future work to assess long-range transport and contributions from nearby McMurdo Station.

\section{ACKNOWLEDGEMENTS}

The researchers would like to acknowledge the following organizations and individuals for making this expedition a success: Government of Malaysia through the Ministry of Science, Technology and Environment (IRPA Grant Nos: 08-02-03-0551 and 08-02-03-0553), the University of Malaya, the Academy of Science Malaysia, Antarctica New Zealand, the New Zealand Embassy, Malaysia and Scott Base personnel (summer and winter-over team).

\section{REFERENCES}

1. Aislabie J., Balks M., Astori N., Stevenson G. and Symons R. (1999). Polycyclic aromatic hydrocarbons in fuel-oil contaminated soils, Antarctica. Chemosphere, 39: 2201-2207.

2. Thompson B.A.W., Goldsworthy P.M., Riddle M.J., Snape I. and Stark J.S. (2007). Contamination effects of conventional and biodegradable lubricant oil on infaunal recruitment to Antarctic sediments: A field experiment. J. Exp. Mar. Biol. Ecol. 340: 213-226.

3. Mazzera, D., Hayes, T., Lowenthal, D. and Zielinska, B. (1999). Quantification of polycyclic aromatic hydrocarbons in soil at McMurdo Station, Antarctica. The Sci. Total Environ. 229:65-71.

4. Aislabie J.M., Balks M.R., Foght J.M. and Waterhouse E.J. (2004). Hydrocarbon spills on Antarctic soils: effects and management. Environ. Sci. Technol., 38:1265-1274.

5. Hughes, K.A. and Stallwood, B. (2005). Oil pollution in the Antarctic Terrestrial Environment. Polarforschung, 75:141-144.

6. Gambaro, A., Manodori, L., Zangrando, R., Cincinelli, A., Capodaglio, G. and Cescon, P. (2005). Atmospheric PCB Concentrations at Terra Nova Bay, Antarctica. Environ. Sci. Technol. 39:9406-9411.

7. Yogui, G.T. and Sericano, J.L. (2008). Polybrominated diphenyl ether flame retardants in lichens and mosses from King George Island, maritime Antarctica, Chemosphere.

Doi:10.1016/j.chemosphere.2008.08.035

8. Klánová, J., Matykiewiczová, N., Máčka, Z., Prošek, P., Láska, K. and Klán, P. (2008). Persistent organic pollutants in soils and sediments from James Ross Island, Antarctica. Environ. Pollut. 152:416-423.

9. Negri, A.P., Hales, L.T., Battershill, C., Wolff, C. and Webster, N.S. (2004). TBT contamination indentified in Antarctic marine sediments. Mar. Pollut. Bull. 48:1142-1144.

10. Bargagli, R. (2008). Environmental contamination in Antarctic ecosystems. Sci. Total Doi:10.1016/j.scitotenv.2008.06.062.

11. Hale, R.C., Kim, S.L., Harvey, E., La Guardia, M.J. Mainor, T.M., Bush, E.O. and Jacobs, E.M. (2008). Antarctic research bases: Local sources of polybrominated 
diphenyl ether (PBDE) flame retardants. Environ. Sci. Technol. 42:1452-1457.

12. Negri, A. Burns, K., Boyle, S. Brinkman, D. and Webster, N. (2006). Contamination in sediments, bivalves and sponges of McMurdo Sound, Antarctica. Environ. Pollut. 143:456-467.

13. Omar, N.S.M.J., Abas, M.R.B., Rahman, N.A., Mohd. Tahir, N., Rushdi, A.I. and Simoneit, B.R.T. (2007). Levels and distributions of organic source tracers in air and roadside dust particles of Kuala Lumpur, Malaysia, Environ. Geol. 52:14851500.

14. Mazzera D.M., Lowenthal D.H., Chow J.C. and Watson J.G. (2001). Sources of $\mathrm{PM}_{10}$ and sulfate aerosol at McMurdo Station, Antarctica. Chemosphere 45: 347-356.

15. Mazzera D.M., Lowenthal D.H., Chow J.C., Watson J.G. and Grubǐsíc V. (2001). PM $_{10}$ measurements at McMurdo Station, Antarctica. Atmos. Environ. 35:1891-1902.

16. Peltzer E.T. and Gagosian R.B. (1987). Sampling and quantitation of lipids in aerosols from the remote marine atmosphere. Anal. Chim. Acta 198: 125144.

17. Sicre M.A., Marty J.C. and Saliot A. (1990). n-Alkanes, fatty acid esters, and fatty acid salts in size fractionated aerosols collected over the Mediterranean sea. J. Geophys. Res. 95(D4): 3649-3657.

18. Mazurek M.A. and Simoneit B.R.T. (1984). Characterization of biogenic and petroleumderived organic matter in aerosols over remote, rural, and urban areas. In: Identification and Analysis of Organic Pollutants in Air (ed. Keith L.H.) Ann Arbor Science, Woburn, M.A. pp. 353-370.

19. Simoneit B.R.T., Cardoso J.N. and Robinson N. (1991). An assessment of terrestrial higher molecular weight lipid compounds in air particulate matter over the South Atlantic from about $30-70^{\circ} \mathrm{S}$. Chemosphere 23: 447-465.

20. Jungblut, A.D., Allen, M.A., Burns, B.P. and Neilan, B.A. (2008). Lipid biomarker analysis of cyanobacterial dominated microbial mats in meltwater ponds on the McMurdo Ice Shelf, Antarctica, Org. Geochem. doi:10.1016/j.orggeochem.2008.10.002.

21. Aislabie J., McLeaod M. and Fraser R. (1998). Potential of biodegradation of hydrocarbons in soil from the Ross dependency, Antarctica. Appl. Microbiol. Biotechnol. 49:210-214.

22. Jaraula C.M.B., Kenig F., Doran P.T., Priscu J.C. and Welch K.A. (2008). SPME-GCMS study of the natural attenuation of aviation diesel spilled on the perennial ice cover of lake Fryxell, Antarctica. Sci. Total Environ. Doi:10.1016/j.scitotenv.2008.07.064

23. Webster, J., Webster, K., Nelson, P. and Waterhouse, E. (2003). The behaviour of residual contaminants at a former station site, Antarctica, Environ. Pollut. 123:163179.

24. Bej A.K., Saul D. and Aislabie J. (2000). Cold-tolerant alkane-degrading Rhodococcus species from Antarctica. Polar Biol. 23:100-105.

25. Abas M.R.B., Simoneit B.R.T., Elias V., Cabral J.A. and Cardoso J.N. (1995). Composition of higher molecular weight organic matter in smoke aerosol from biomass combustion in Amazonia. Chemosphere 30: 995-1015.

26. Simoneit B.R.T., Rushdi A.I., Abas M.R.B. and Didyk B.M. (2003). Alkyl amides and nitriles as novel tracers for biomass burning. Environ. Sci. Technol. 37: 16-21.

27. Duan Y. (2000). Organic geochemistry of recent marine sediments from the Nansha Sea, China. Org. Geochem. 31: 159-167.

28. Jaffé R., Mead R., Hernandez M.E., Peralba M.C. and DiGuida O.A. (2001). Origin and transport of sedimentary organic matter in two subtropical estuaries: a comparative, biomarker-based study. Org. Geochem. 32: 507-526.

29. Simoneit B.R.T. (1985). Application of molecular marker analysis to vehicular exhaust for source reconciliation. Int. J. Environ. Anal. Chem. 22: 203-233.

30. Simoneit B.R.T. and Mazurek M.A. (1982). Organic matter of the troposphere-II. Natural background of biogenic lipid matter in aerosols over the rural Western United States. Atmos. Environ. 16: 2139-2159.

31. Simoneit B.R.T. (1984). Organic matter of the troposphere-III. Characterization and sources of petroleum and pyrogenic residues in aerosols over the Western United States. Atmos. Environ. 18: 51-67.

32. Caricchia A.M., Chiavarini S., Cremisini C., Fantini M., Morabito R., Perini A. and Pezza M. (1993). PAHs in atmospheric particulate in the area of Italian scientific base in Antarctica. Water Sci. Technol. 27: 235243. 
33. Caricchia A.M., Chiavarini S., Cremisini C., Morabito R., Perini A. and Pezza M. (1995). Determination of $\mathrm{PAH}$ in atmospheric particulate in the area of the Italian Base in Antarctica: report on monitoring activities during the last three scientific expeditions. Environ. Pollut. 87: 345-356.

34. Rogge W.F., Hildemann L.M., Mazurek M.A., Cass G.R. and Simoneit B.R.T. (1993). Sources of fine organic aerosol. 2.
Noncatalyst and catalyst-equipped automobiles and heavy-duty diesel trucks. Environ. Sci. Technol. 27: 636-651.

35. Venkataraman C., Lyons J.M. and Friedlander S.K. (1994). Size distributions of polycyclic aromatic hydrocarbons and elemental carbon. 1. Sampling, measurement methods, and source characterization. Environ. Sci. Technol. 28: 
Table 1. The atmospheric conditions prevailing during the days of sampling

\begin{tabular}{lcc}
\hline & Spring $($ October 1999) & Winter (July/August 2000) \\
\hline $\begin{array}{l}\text { Maximum air } \\
\text { temperature }\end{array}$ & $-10.0^{\circ} \mathrm{C}$ & $-10.7^{\circ} \mathrm{C}$ \\
$\begin{array}{l}\text { Minimum air } \\
\text { temperature }\end{array}$ & $-18.0^{\circ} \mathrm{C}$ & $-44.3^{\circ} \mathrm{C}$ \\
Wind $(\mathrm{m} / \mathrm{s})$ & $\mathrm{NE}(10.3)$ & $\mathrm{NE}, \mathrm{SW}(13.0-29.0)$ \\
\hline
\end{tabular}

Table 2. General characteristics of samples collected at Scott Base and Arrival Heights

\begin{tabular}{lccc}
\hline No. & Sample [Date, $\begin{array}{l}\text { Volume Sampled }\left(\mathrm{m}^{3}\right) / \text { weight } \\
\text { Extracted }(\mathrm{g})]\end{array}$ & TSEOM $\left(\mathrm{ng} \mathrm{m}^{-3}, \mu \mathrm{g} \mathrm{g}^{-1}\right)$ & TSP $\left(\mu \mathrm{g} \mathrm{m}^{-3}\right)$ \\
\hline
\end{tabular}

A. Atmospheric Particles

\section{Spring (October 1999)}

1 Arrival Heights 1 [18/10/1999, 2854.4]

$308.30 \quad 20.58$

Arrival Heights $2[21 / 10 / 1999,1141.7]$

$823.33 \quad 30.28$

Flagpole 1 [16/10/1999, 1569.9]

$535.07 \quad 23.15$

Flagpole $2[22 / 10 / 1999,1427.2]$

$910.87 \quad 28.16$

Flagpole 3 [23/10/1999, 1427.2]

$518.50 \quad 21.50$

Tower 1 [19/10/1999, 1407.5]

$1747.78 \quad 15.41$

Tower 2 [20/10/1999, 1427.2]

Incinerator 1 [18/10/1999, 1427.2]

$1611.55 \quad 22.11$

$560.54 \quad 20.68$

$420.40 \quad 20.30$

$2130.04 \quad 34.84$

10 Garage 1 [21/10/1999, 1427.2]

11 Garage $2[22 / 10 / 1999,1427.2]$

$994.96 \quad 29.22$

2. Winter (July/August 2000)

12 Winter $1[5 / 07 / 2000,1427.2$

532.51

29.17

13 Winter $2[12 / 07 / 2000,1427.2]$

$546.52 \quad 31.12$

Winter 3 [18/07/2000, 1427.2]

$490.47 \quad 29.06$

15 Winter 4 [21/07/2000, 1427.2]

$420.40 \quad 21.46$

\section{Summer (February 2001)}

16 Arrival Heights $3[6 / 02 / 2001,1427.2]$

1177.13

25.29

17 Arrival Heights 4 [7/02/2001, 2854.4]

$2704.60 \quad 20.72$

18 Flagpole $4(4 / 02 / 2001,1427.2]$

$2003.92 \quad 19.62$

19 Flagpole 5(5/02/2001, 1442.0]

2413.31

21.27

B. Soils

1 Arrival Heights [18/10/1999, 10.01] 51.95

2 Flagpole [16/10/1999, 10.00] 46.00

3 Garage [16/10/1999, 10.01] 423.58

4 Incinerator [18/10/1999, 10.00] 128.00

5 Summer Lab [16/10/1999, 10.00] 204.00

6 Incinerator (Ash) [19/10/1999, 10.01] 77.92 


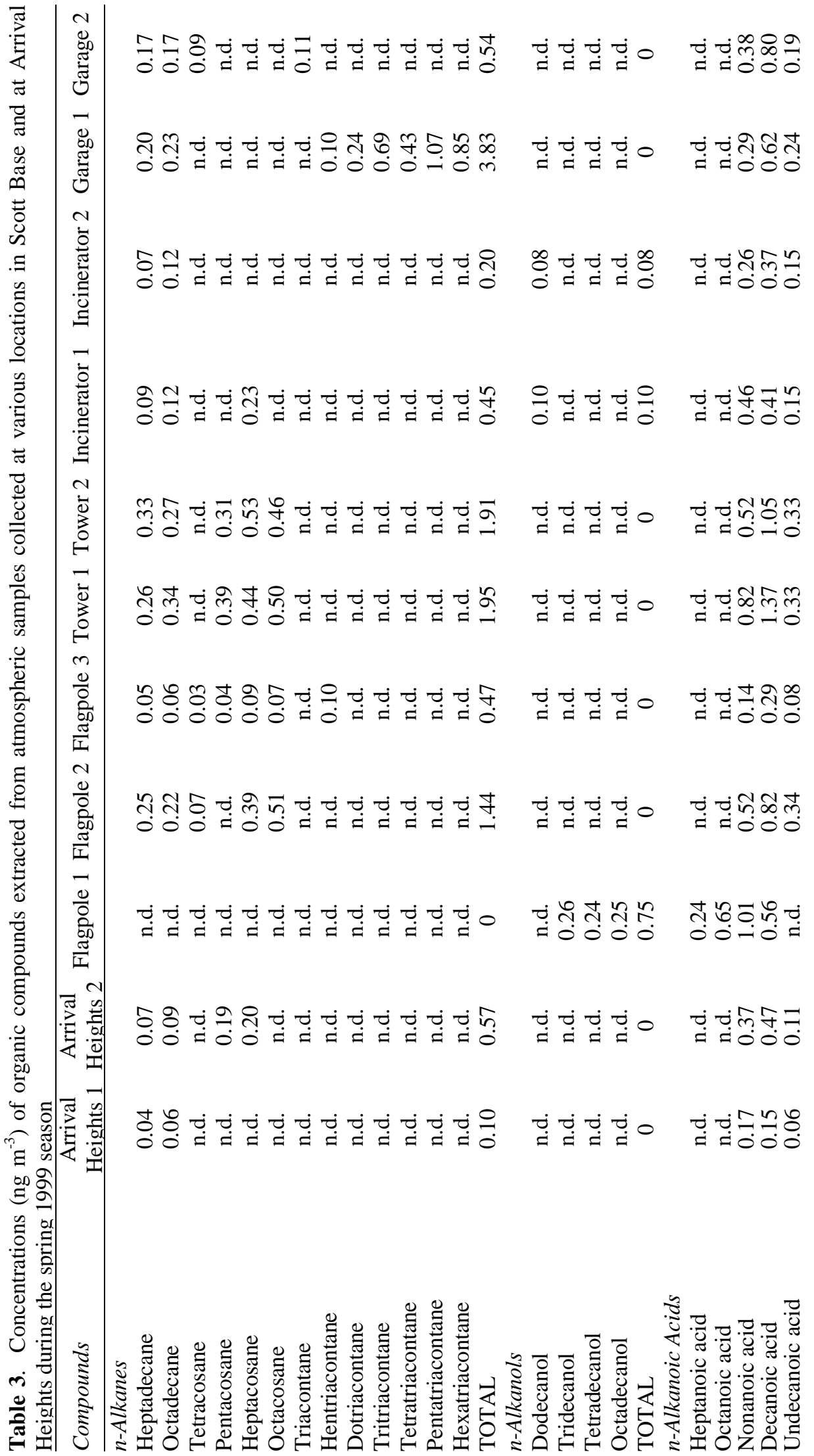




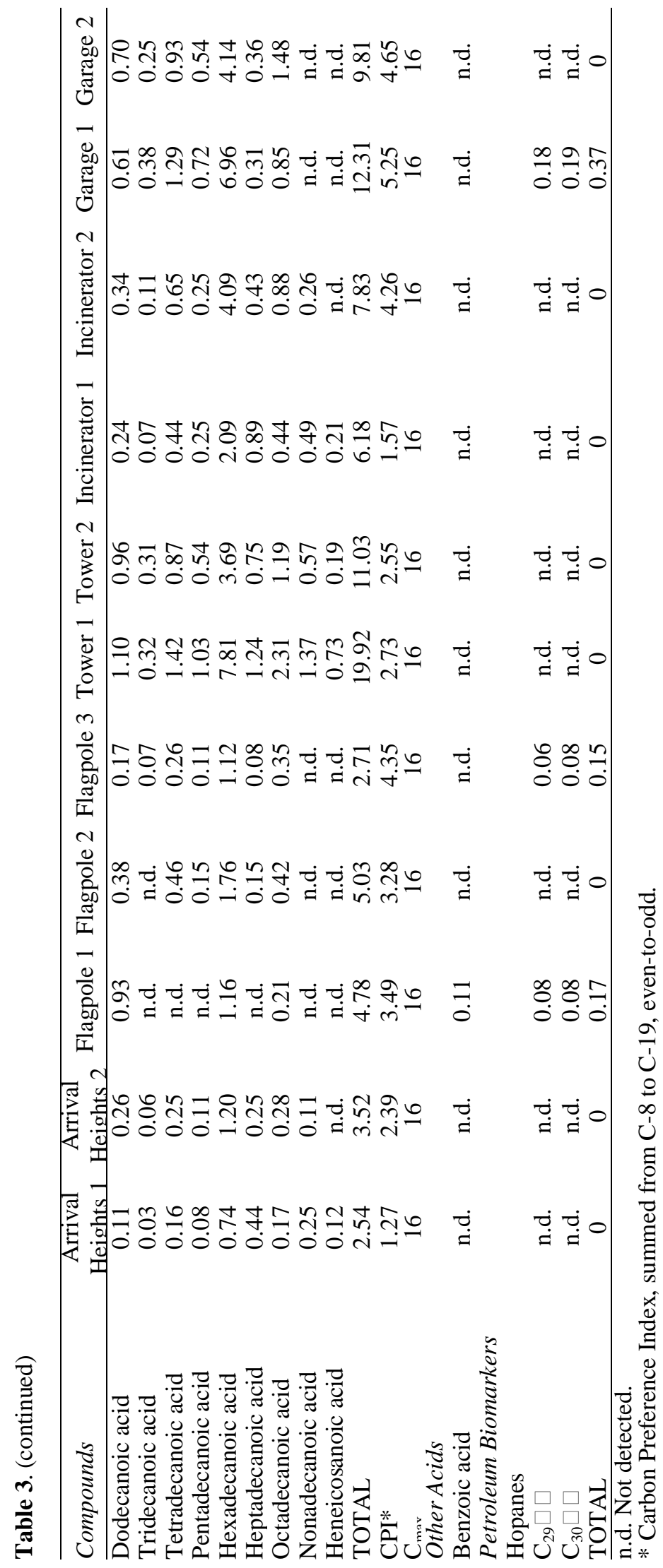




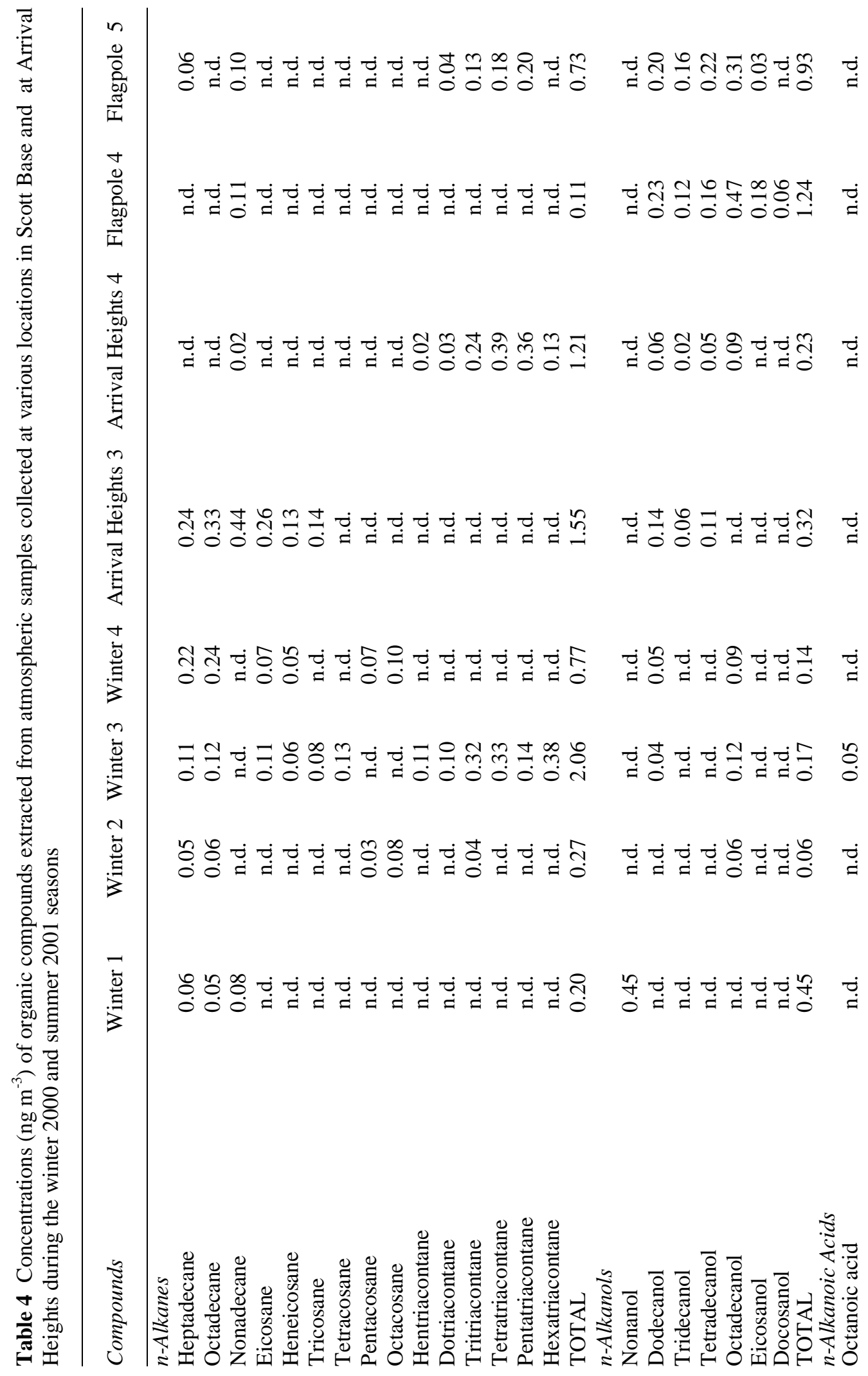




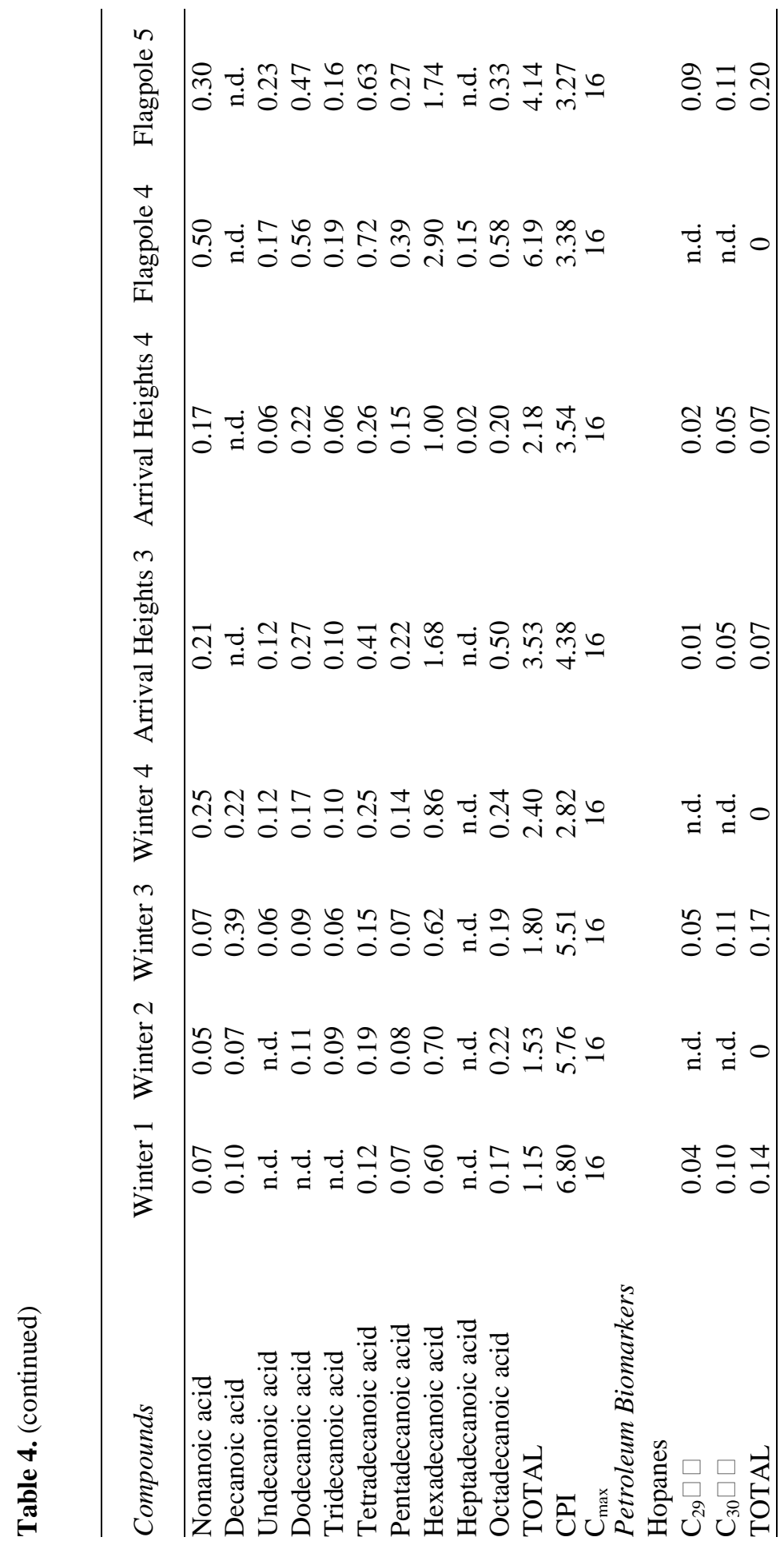


Table 5 Concentrations $\left(\mathrm{ng} \mathrm{g}^{-1}\right)$ of organic compounds extracted from the soil samples collected at various locations in Scott Base and at Arrival Heights during the spring of 1999

\begin{tabular}{|c|c|c|c|c|c|c|}
\hline Compounds & $\begin{array}{c}\text { Arrival } \\
\text { Heights }\end{array}$ & Flagpole & Garage & Incinerator & $\begin{array}{c}\text { Summer } \\
\text { Lab }\end{array}$ & $\begin{array}{c}\text { Incinerator } \\
\text { (Ash) }\end{array}$ \\
\hline \multicolumn{7}{|l|}{$\overline{n \text {-Alkanes }}$} \\
\hline Tetradecane & n.d. & n.d. & n.d. & 2.30 & 48.59 & 3.26 \\
\hline Pentadecane & n.d. & n.d. & n.d. & 3.83 & 106.66 & 10.89 \\
\hline Hexadecane & n.d. & n.d. & n.d. & 5.399 & 97.740 & 11.227 \\
\hline Heptadecane & 4.19 & 2.92 & 136.88 & 7.71 & 116.25 & 31.29 \\
\hline Octadecane & 5.03 & 3.39 & 36.32 & 7.79 & 41.24 & 15.25 \\
\hline Nonadecane & n.d. & n.d. & 30.15 & 6.14 & 28.38 & 7.52 \\
\hline Eicosane & 3.42 & 2.85 & 19.34 & 4.93 & 21.35 & 24.48 \\
\hline Heneicosane & 4.24 & 1.85 & 13.52 & 4.09 & 14.49 & 14.48 \\
\hline Docosane & n.d. & 2.25 & 8.29 & 4.47 & 11.86 & 23.15 \\
\hline Tricosane & 2.89 & 1.95 & n.d. & n.d. & 14.36 & 15.66 \\
\hline Tetracosane & n.d. & 2.81 & n.d. & n.d. & 23.65 & 33.38 \\
\hline Pentacosane & n.d. & n.d. & n.d. & n.d. & n.d. & 27.87 \\
\hline Hexacosane & n.d. & n.d. & 21.30 & n.d. & 5.09 & 40.49 \\
\hline Heptacosane & n.d. & n.d. & n.d. & n.d. & n.d. & 45.69 \\
\hline Octacosane & n.d. & n.d. & n.d. & n.d. & n.d. & 60.69 \\
\hline Nonacosane & n.d. & n.d. & n.d. & n.d. & n.d. & 52.61 \\
\hline Triacontane & n.d. & n.d. & n.d. & n.d. & n.d. & 48.42 \\
\hline Hentriacontane & n.d. & n.d. & n.d. & n.d. & n.d. & 65.77 \\
\hline Dotriacontane & n.d. & n.d. & n.d. & n.d. & n.d. & 54.54 \\
\hline Tritriacontane & n.d. & n.d. & n.d. & n.d. & n.d. & 30.26 \\
\hline Tetratriacontane & n.d. & n.d. & n.d. & n.d. & n.d. & 27.98 \\
\hline Pentatriacontane & n.d. & n.d. & n.d. & n.d. & n.d. & 28.30 \\
\hline Hexatriacontane & n.d. & n.d. & n.d. & n.d. & n.d. & 17.99 \\
\hline Heptatriacontane & n.d. & n.d. & n.d. & n.d. & n.d. & 19.04 \\
\hline \multicolumn{6}{|l|}{ n-Alkenes } & 710.35 \\
\hline Pentadecene & n.d. & n.d. & n.d. & n.d. & n.d. & 6.86 \\
\hline Hexadecene & n.d. & n.d. & n.d. & n.d. & n.d. & 5.92 \\
\hline Heptadecene & n.d. & n.d. & n.d. & n.d. & n.d. & 12.55 \\
\hline Octadecene & n.d. & n.d. & n.d. & n.d. & n.d. & 10.42 \\
\hline Nonadecene & n.d. & n.d. & n.d. & n.d. & n.d. & 6.04 \\
\hline Eicosene & n.d. & n.d. & n.d. & n.d. & n.d. & 9.12 \\
\hline Heneicosene & n.d. & n.d. & n.d. & n.d. & n.d. & 14.86 \\
\hline Docosene & n.d. & n.d. & n.d. & n.d. & n.d. & 23.58 \\
\hline Tricosene & n.d. & n.d. & n.d. & n.d. & n.d. & 8.41 \\
\hline Tetracosene & n.d. & n.d. & n.d. & n.d. & n.d. & 7.82 \\
\hline Pentacosene & n.d. & n.d. & n.d. & n.d. & n.d. & 9.58 \\
\hline Hexacosene & n.d. & n.d. & n.d. & n.d. & n.d. & 11.78 \\
\hline TOTAL & 0 & 0 & 0 & 0 & 0 & 127.00 \\
\hline \multicolumn{7}{|l|}{ n-Alkyl nitriles } \\
\hline Heptadecyl nitrile & n.d. & n.d. & n.d. & n.d. & n.d. & 26.04 \\
\hline $\begin{array}{l}\text { TOTAL } \\
\text { n-Alkanol }\end{array}$ & 0 & 0 & 0 & 0 & 0 & 74.85 \\
\hline $\begin{array}{l}n \text {-Alkano } \\
\text { Decanol }\end{array}$ & n.d. & n.d. & n.d. & n.d. & n.d. & 2.68 \\
\hline Dodecanol & n.d. & n.d. & n.d. & n.d. & n.d. & 9.58 \\
\hline Octadecanol & 3.98 & 2.23 & 13.05 & 3.51 & 11.04 & 6.84 \\
\hline TOTAL & 3.98 & 2.23 & 13.05 & 3.51 & 11.04 & 19.11 \\
\hline
\end{tabular}


Table 5 (continued)

\begin{tabular}{|c|c|c|c|c|c|c|}
\hline Compounds & $\begin{array}{l}\text { Arrival } \\
\text { Heights }\end{array}$ & Flagpole & Garage & Incinerator & $\begin{array}{l}\text { Summer } \\
\text { Lab }\end{array}$ & $\begin{array}{c}\text { Incinerator } \\
\text { (Ash) }\end{array}$ \\
\hline \multicolumn{7}{|l|}{$\overline{n \text {-Alkanoic Acids }}$} \\
\hline Octanoic acid & 3.67 & 3.69 & n.d. & 5.51 & 54.73 & 3.24 \\
\hline Nonanoic acid & 3.48 & 2.53 & n.d. & 4.49 & 64.80 & 3.49 \\
\hline Decanoic acid & 3.61 & 3.23 & n.d. & 4.60 & 94.84 & 3.54 \\
\hline Undecanoic acid & 1.19 & n.d. & n.d. & 1.94 & n.d. & n.d. \\
\hline Dodecanoic acid & 6.77 & 4.87 & n.d. & 5.71 & 25.12 & 6.98 \\
\hline Tetradecanoic acid & 10.50 & 7.96 & 30.29 & 16.55 & 67.76 & 12.60 \\
\hline Pentadecanoic acid & 7.06 & 3.69 & n.d. & 6.91 & 23.95 & n.d. \\
\hline Hexadecanoic acid & 48.51 & 42.64 & 104.88 & 58.07 & 151.21 & 37.06 \\
\hline Heptadecanoic acid & 2.85 & n.d. & n.d. & n.d. & n.d. & n.d. \\
\hline Octadecanoic acid & 9.63 & 6.24 & 27.66 & 9.69 & 51.15 & 7.86 \\
\hline Nonadecanoic acid & 2.04 & n.d. & n.d. & n.d. & n.d. & n.d. \\
\hline TOTAL & 99.35 & 74.90 & 162.84 & 113.49 & 533.59 & 74.80 \\
\hline CPI & 4.9 & 11.02 & - & 7.50 & 5.01 & 20.4 \\
\hline $\mathrm{C}_{\max }$ & 16 & 16 & 16 & 16 & 16 & 16 \\
\hline \multicolumn{7}{|l|}{ Petroleum } \\
\hline \multicolumn{7}{|l|}{ Isoprenoids } \\
\hline Pristane & n.d. & n.d. & 6.70 & n.d. & 6.30 & n.d. \\
\hline Phytane & n.d. & n.d. & 2.80 & n.d. & 1.64 & n.d. \\
\hline TOTAL & 0 & 0 & 9.50 & 0 & 7.95 & 0 \\
\hline \multicolumn{7}{|l|}{ Hopanes } \\
\hline $\mathrm{C} 29 \square \square$ & n.d. & n.d. & 9.60 & 50.34 & 24.87 & n.d. \\
\hline C30 $\square$ & n.d. & n.d. & 9.92 & 39.59 & 22.17 & n.d. \\
\hline 22S-C31 $\square \square$ & n.d. & n.d. & 5.80 & 23.09 & 7.20 & n.d. \\
\hline 22R-C31 $\square \square$ & n.d. & n.d. & 3.26 & 14.60 & 3.77 & n.d. \\
\hline 22S-C32 $\square \square$ & n.d. & n.d. & n.d. & 9.73 & n.d. & n.d. \\
\hline 22R-C32 $\square \square$ & n.d. & n.d. & n.d. & 6.81 & n.d. & n.d. \\
\hline 22S-C33 $\square \square$ & n.d. & n.d. & n.d. & 4.99 & n.d. & n.d. \\
\hline 22R-C33 $\square \square$ & n.d. & n.d. & n.d. & 3.80 & n.d. & n.d. \\
\hline TOTAL & 0 & 0 & 28.60 & 152.98 & 58.03 & 0 \\
\hline \multicolumn{7}{|l|}{ Steranes } \\
\hline 20S-C29 $\square \square-$ & n.d. & n.d. & n.d. & 2.79 & 1.18 & n.d. \\
\hline 20R-C29 $\square \square \square-$ & n.d. & n.d. & n.d. & 6.19 & 2.27 & n.d. \\
\hline 20S-C29 $\square \square \square-$ & n.d. & n.d. & n.d. & 5.74 & 2.01 & n.d. \\
\hline 20R-C29 $\square \square \square-$ & n.d. & n.d. & n.d. & 5.29 & 1.91 & n.d. \\
\hline TOTAL & 0 & 0 & 0 & 20.01 & 7.38 & 0 \\
\hline
\end{tabular}

